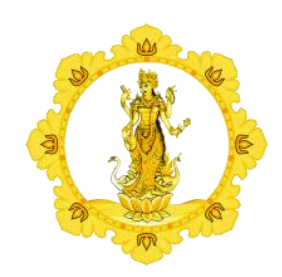

KALANGWAN

JURNAL PENDIDIKAN AGAMA, BAHASA DAN SASTRA

Vol. 9 No. 2 September 2019

\begin{tabular}{|l|l|l|}
\hline p-ISSN : 1979-634X & e-ISSN : 2686-0252 & http://ejournal.ihdn.ac.id/index.php/Kalangwan \\
\hline
\end{tabular}

\title{
HUBUNGAN GEGURITAN BRAYUT DENGAN SOSIAL BUDAYA MASYARAKAT BALI
}

\author{
Oleh : \\ A.A. Diah Indrayani \\ Institut Hindu Dharma Negeri Denpasar \\ E-mail: diahindra17@gmail.com
}

Diterima 14 Juli 2019, direvisi 11 Agustus 2019, diterbitkan 2 September 2019

\begin{abstract}
Literature and culture have the same object that is a human being which existed in a community as a social fact and as a cultural creature. They have a special place in a society due to their close relationship. The figure can be found on a various art creations in Bali such as painting, sculpture and traditional song. Meanwhile, the government promotes family planning as a program to the citizen. The problems discussed on this research is how the relation between geguritan Brayut and social and cultural of the Balinese.

The methodology of this study is a qualitative research through non-interactive research by analyzing a textual research which is not related to the community on its organic environment. The research approach used in this study is thematic philosophy. The theory applied in this research are theory of deconstruction and semiotic.

The result of this research shows that the relation between Geguritan Brayut with social and culture of Balinese community can be seen on their marriage concept according to Hindu belief, family prosperity, child nurture, the genetic system (matrilineal and patrilineal).
\end{abstract}

Keywords: Geguritan Brayut, Social and Culture

\section{PENDAHULUAN}

Karya sastra merupakan bagian dari kebudayaan, kelahirannya di tengah-tengah masyarakat tidak luput dari pengaruh sosial dan budaya. Pengaruh tersebut bersifat timbal balik, artinya karya sastra dapat mempengaruhi dan dipengaruhi oleh masyarakat. Karya sastra adalah gambaran kehidupan. Walaupun sebagai gambaran, karya sastra tidak pernah menjiplak kehidupan (imitated but not duplicated). 
Sapardi Djoko Damono (2005:45) menegaskan bahwa sastra menampilkan gambaran kehidupan itu sebagai suatu kenyataan sosial yang menyangkut hubungan masyarakat dengan orang perorang, antara manusia dan antara peristiwa yang terjadi dalam batin seseorang. Menurut Sapardi Djoko Damono (2005:26), bagaimanapun juga peristiwa yang terjadi dalam batin seseorang yang menjadi bahan sastra adalah pantulan hubungan seseorang dengan orang lain atau dengan masyarakat. Selaras dengan pendapat Sapardi Djoko Damono tersebut, Jakob Sumardjo (2000:34) menyatakan bahwa "perkembangan individu sastrawan banyak dipengaruhi oleh faktor lingkungan, termasuk masyarakatnya. Seorang sastrawan belajar menjadi sastrawan dari lingkungan masyarakatnya. Latar belakang sosial dan budaya masyarakat memengaruhi bentuk pemikiran dan ekspresi sastrawan". Jadi, karya sastra seorang pengarang mengandung nilai-nilai kognitif konteks budaya dan nilainilai ideal kehidupan pengarang.

Geguritan merupakan salah satu bentuk karya sastra yang di dalamnya memuat nilainilai estetika dan nilai-nilai pengetahuan serta nilai-nilai kehidupan. Dengan demikian, sastra sebagai teks harus dilihat pula dalam konteks. Seorang pengarang menciptakan novel dalam konteks tertentu, cerita yang dilukiskan didalamnya bersumber dari masyarakat imajiner yang dikehendaki atau ditolaknya. Oleh sebab itu, pengarang sebagai bagian dari masyarakat dengan kekuatan imajinasinya dapat melahirkan sebuah karya sastra dari permasalahan sosial masyarakat yang melingkupinya. Iaselalu terikat oleh pengalaman hidupnya, pengetahuannya, pendidikannya, tradisinya, wawasan seninya, dan sebagainya. Ia hidup dan berelasi dengan orang-orang dan lingkungan sosial budaya di sekitarnya, maka tak mengherankan kalau terjadi interaksi dan relasi antara pengarang dan masyarakatnya. Kegelisahan masyarakat menjadi kegelisahan para pengarang. Begitu pula harapan-harapan, penderitaanpenderitaan, aspirasi mereka menjadi bagian pola diri pribadi pengarang-pengarangnya. Itulah sebabnya sifat dan persoalan suatu zaman dapat dibaca dalam karya-karya sastranya (Jakob Sumardjo dan Saini K.M, 1991:3).

Pernyataan di atas menandakan bahwa suatu karya sastra tidak akan cukup diteliti dari aspek strukturnya saja tanpa kerjasama dengan disiplin ilmu lain, karena masalah yang terkandung di dalam karya sastra pada dasarnya merupakan masalah masyarakat. Adakalanya, seni sastra juga dapat mewakili kehidupan masyarakat pada saat karya sastra itu diciptakan. Karya sastra diciptakan untuk dinikmati, dipakai, dan dimanfaatkan oleh masyarakat. Pengkajian terhadap karya sastra merupakan pemahaman karya sastra yang lebih baik. Dengan demikin karya sastra dapat dinikmati lebih intens serta dapat dimanfaatkan untuk memahami hidup ini (Teeuw, 1984:18). Selain untuk dinikmati, karya sastra juga perlu dikritisi baik dalam bentuk memberikan pujian, mengatakan kesalahan, memberikan pertimbangan lewat pemahaman dan penafsiran sistematik yang disebut kritik sastra. Kritik sastra juga berfungsi untuk menemukan nilai-nilai yang terkandung dalam karya sastra tersebut. Dalam bab ini akan dibahas mengenai hubungan sosial budaya diantaranya adalah perkawinan menurut Hindu, kesejahteraan keluarga, masalah pengasuhan anak dan sistem kekerabatan.

\section{PEMBAHASAN}

2.1 Perkawinan Menurut Hindu

Secara etimologi, perkawinan adalah kata benda turunan dari kata kerja dasar kawin, kata itu berasal dari kata Jawa kuno ka-awin atau ka-ahwin yang berarti dibawa, dipikul, diboyong, kata ini adalah bentuk pasif dari kata Jawa kuno awin atau ahwin, selanjutnya kata itu berasal dari kata vini dalam bahasa Sansekerta

\subsubsection{Definisi Perkawinan Menurut Hindu \\ Perkawinan atau wiwaha dalam agama} Hindu merupakan yadnya dan perbuatan dharma. Wiwaha atau perkawinan merupakan momentum awal dari Grhasta Ashram yaitu tahapan kehidupan berumah tangga. Dalam adat Hindu Bali merupakan upaya untuk 
mewujudkan hidup Grhasta Ashram, tugas pokoknya menurut lontar Agastya Parwa adalah mewujudkan suatu kehidupan yang disebut "Yatha sakti kayika dharma" yang artinya dengan kemampuan sendiri melaksanakan dharma. Jadi seorang Grhasta harus benar-benar mampu mandiri mewujudkan dharma secara profesional haruslah dipersiapkan oleh seorang Hindu yang ingin menempuh jenjang perkawinan. Grhasta Ashram secara sah dimulai pada saat seorang laki-laki dan seorang wanita mengangkat sumpah untuk hidup bersama dengan direstui dan disaksikan oleh kedua orangtua/wali, diberkati dengan mantra suci Veda oleh pinandita, dan dicatat oleh Parisadha Hindu Dharma.

Veda mengatakan bahwa pernikahan dalam Hindu adalah suatu perbuatan suci. Ada dua maksud utama di dalamnya. Pertama, Tuhan memberkati laki-laki dan perempuan untuk saling mencintai sebagaimana Dewa Smara (sama seperti Adam) dan Dewi Ratih (sama seperti Hawa). Kedua, manusia diberi kesempatan untuk bereinkarnasi melaui keturunan yang dihasilkan oleh sepasang suami istri tersebut. Itu sebabnya mengapa melahirkan keturunan masuk dalam prioritas pernikahan bagi masyarakat Hindu di Bali.

Untuk memberikan pengertian yang lebih jelas tentang arti dan tujuan perkawinan, dapat ditinjau dari UU Perkawinan No. 1 Tahun 1974, sebagai berikut :

"Perkawinan adalah ikatan lahir bathin antara seorang pria dengan wanita sebagai suami istri dengan tujuan membentuk keluarga (rumah tangga) yang bahagia dan kekal berdasarkan Ketuhanan Yang Maha Esa"

Benny (2006:6-8) mengatakan unsurunsur perkawinan yaitu:

1. Perkawinan adalah ikatan lahir bathin antara seorang pria dengan seorang wanita

2. Perkawinan adalah pertalian yang sah antara seorang laki-laki dan seorang perempuan untuk waktu yang lama
3. Perkawinan merupakan hubungan hukum antara seorang pria dengan seorang wanita, untuk hidup bersama dengan kekal yang diakui negara

4. Perkawinan adalah social institution atau pranata sosial yaitu kebiasaan yang diikuti resmi sebagai suatu gejala-gejala sosial

5. Perkawinan itu menyangkut persoalan kerabat, keluarga, masyarakat, martabat dan pribadi dan begitu pula menyangkut persoalan keagamaan. Dengan terjadinya perkawinan, maka suami istri mempunyai kewajiban memperoleh keturunan yang akan menjadi penerus silsilah orangtua dan kerabat.

\subsubsection{Tujuan Perkawinan}

Pada dasarnya manusia selain sebagai makhluk individu juga sebagai makhluk sosial, sehingga mereka harus hidup bersamasama untuk mencapai tujuan-tujuan tertentu. Perkawinan merupakan peristiwa suci dan kewajiban bagi umat Hindu karena Tuhan telah bersabda dalam Manawa Dharmasastra IX.96 sebagai berikut:

"Prnja nartha striyah srstah samtarnartham ca manavah

Tasmat sadahrano dharmah crutam patnya sahaditah"

Artinya:

Untuk menjadi ibu, wanita diciptakan dan untuk menjadi ayah, laki-laki itu diciptakan. Upacara keagamaan karena itu ditetapkan di dalam Veda untuk dilakukan oleh suami dengan istrinya.

Adapun tiga tujuan pernikahan menurut ajaran agama Hindu menurut kitab Manawa Dharmasastra, yaitu:

1. Dharmasampati, kedua mempelai secara bersama-sama melaksanakan dharma yang meliputi semua aktivitas dan kewajiban agama seperti melaksanakan yadnya, sebab di dalam tahap kehidupan grhasta yadnya dapat dilakukan dengan sempurna

2. Praja, kedua mempelai mampu melahirkan keturunan yang akan 
melanjutkan amanat dan kewajiban kepada leluhur. Melalui yadnya dan lahirnya putra yang suputra seorang anak akan dapat melunasi hutang jasa kepada leluhur (pitra rna), kepada Dewa (dewa rna) dan kepada para guru (rsi rna).

3. Rati, kedua mempelai dapat menikmati kepuasan seksual dan kepuasan-kepuasan lainnya (artha dan kama) yang tidak bertentangan dan berlandaskan dharma.

Tujuan lain dari pernikahan menurut ajaran Hindu adalah membentuk keluarga (rumah tangga) yang bahagia dan kekal maka dalam agama Hindu sebagaimana diutarakan dalam kitab suci Veda perkawinan adalah terbentuknya sebuah keluarga yang berlangsung sekali dalam hidup manusia. Hal tersebut dituangkan dalam ManawaDharmasastra IX.101-102 sebaga berikut :

"Anyonyasyawayabhicaroghaweama rnantikah, esa dharmah samasenajneyah stripumsayoh parah"

Artinya:

Hendaknya supaya hubungan yang setia berlangsung sampai mati, singkatnya ini harus dianggap sebagai hukum tertinggi sebagai suami istri

"Tatha nityam yateyam stripumasu tu kritakriyau, jatha nabhicaretam tau wiyuktawitaretaram"

Artinya:

Hendaknya laki-laki dan perempuan yang terikat dalam ikatan perkawinan, mengusahakan dengan tidak jemu-jemunya suoaya mereka tidak bercerai dan jangan hendaknya melanggar kesetiaan antara satu dengan yang lain.

"Samtusto bharyarya bharta bharta tathaiva ca, yasminnewa kule nityam kalyanam tatra wa dhruwam"

Artinya:
Pada keluarga dimana suami berbahagia dengan istrinya dan demikian pula sang istri terhadap suaminya, kebahagiaan pasti kekal.

Dalam teks geguritan Brayut ini makna-makna pernikahan telah dituangkan dengan sangat baik oleh penulis pada sosok tokoh Pan Brayut dan istrinya, Men Brayut. Dimana Pan Brayut dan Men Brayut dapat membina rumah tangga yang rukun dan bahagia bersama kedelapan belas anakanaknya hingga anak-anaknya semua menjadi anak yang sukses dan menjadi panutan dari semua warga di desa tersebut. Mereka berdua memiliki kesadaran satu sama lain untuk tidak mengakhiri pernikahan mereka meskipun sempat beradu mulut dan saling mencaci maki satu sama lain, mereka mampu mengendalikan emosi mereka masingmasing. Men Brayut juga diceritakan telah memenuhi kewajibannya sebagai seorang istri dengan mengikuti dan mendukung kata-kata dari suaminya, Pan Brayut. Dia tidak melanggar apa yang dikatakan Pan Brayut. Begitu pula Pan Brayut telah menunaikan kewajibannya sebagai seorang suami, dapat membina rumah tangganya dengan baik. Dalam teks geguritan Brayut, hal tersebut terdapat pada kutipan di bawah ini:

dadi enduh makadadua, pada manglegayang ati, tan kocap suba makelo, pianaknyane pada kelih, ne muwani-muwani, maskaya pada mampuh, pada mangidep badah, ne eluh-luh suba kelih, ayu-ayu,

liyu anake nyaumang.

Terjemahan:

akhirnya keduanya sadar, keduanya saling mengerti/menyadari, diceritakan, anak-anaknya sudah besar, yang laki-laki, sudah mampu menghasilkan, mereka semua beribadah, yang perempuan sudah dewasa, cantik-cantik, 
banyak orang yang sudah memperistri.

Dalam RgVeda X.85.46 disebutkan bahwa tugas dan kewajiban sebagai seorang istri dan suami sebagai berikut:

"Samraajni svasure bhava, samraajni svasrvam bhava, nanandari samraajni bhava, samraajni adhi devrsu"

Artinya:

Wahai mempelai wanita, jadilah nyonya rumah tangga yang sesungguhnya, dampingilah ayah ibu mertuamu, dampingilah saudarisaudari iparmu

Dalam Yajurveda XIV.22 disebutkan bahwa:

"Yantri raad yantri asi yamani, dhruvaa asi dharitrii"

Artinya:

Wahai wanita jadilah pengawas

keluarga yang cemerlang,

tegakkanlah aturan keluarga, dan

jadilah penopang keluarga. bahwa:

Dalam Rgveda X.85.43 disebutkan

"Viirasuup devakaamaa syonaa, sam no bhava dvipade, sam catuspade" Artinya:

Wahai wanita, lahirkanlah keturunan yang cerdas, gagah dan berani, pujalah selalu Hyang Widhi, jadilah insan yang ramah dan menyenangkan kepada semua orang.

Dalam Atharvaveda XIV.1.52 disebutkan bahwa:

"Mameyam astu posyaa, mahyam tvaadaad brhaspatih, mayaa patyaa Artinya:

prajaavati, sam jiiva saradah satam"

Engkau istriku, yang dianugerahkan

Hyang Widhi padaku, aku akan mendukung dan melindungimu. Semoga kau hidup berbahagia bersamaku dan anak keturunan kita sepanjang masa.
2.2 Kesejahteraan Keluarga

\subsubsection{Definisi Kesejahteraan Keluarga}

Kesejahteraan adalah hal atau keadaan sejahtera, aman, selamat dan tenteram (Depdiknas, 2001:1011). Keluarga sejahtera adalah keluarga yang dibentuk berdasarkan perkawinan yang sah, mampu memenuhi kebutuhan hidup spiritual dan materi yang layak, bertakwa pada Tuhan Yang Maha Esa, memiliki hubungan yang selaras, serasi, dan seimbang antar anggota dan antar keluarga dengan masyarakat dan lingkungan (BKKBN, 1994:5). Kesejahteraan keluarga tidak hanya menyangkut kemakmuran saja, melainkan juga harus secara keseluruhan sesuai dengan ketenteraman yang berarti dengan kemampuan itulah dapat menuju keselamatan dan ketenteraman hidup. UU No.10 Tahun 1992 pasal 3 ayat 2 menyebutkan bahwa pembangunan keluarga sejahtera diarahkan pada pembangunan kualitas keluarga yang bercirikan kemandirian, ketahanan keluarga dan kemandirian keluarga. Kesejahteraan adalah suatu tata kehidupan sosial, material, maupun spiritual yang diliputi rasa keselamatan, kesusilaan dan ketenteraman lahir bathin yang memungkinkan setiap warga negara untuk mengadakan usaha-usaha pemenuhan kebutuhan jasmani, rohani, dan sosial yang sebaik-baiknya bagi diri, rumah tangga serta masyarakat (Rambe, 2001:54). Persepsi masyarakat mengenai kesejahteraan juga berbeda-beda. Oleh karena itu membutuhkan penjabaran yang detail dan hati-hati dengan memperhatikan keragaman dan kondisi sosial budaya masyarakat (Soembodo, 2004:16).

\subsubsection{Tujuan Keluarga Sejahtera}

Keluarga yang sejahtera bertujuan untuk mengembangkan keluarga agar timbul rasa aman, tenteram, dan harapan masa depan yang lebih baik merupakan salah satu pembentuk ketahanan keluarga dalam membangun keluarga sejahtera. Dalam PP No.21 tahun 1994 pasal 2 menyebutkan bahwa pembangunan keluarga sejahtera diwujudkan melalui pengembangan kualitas keluarga diselenggarakan secara menyeluruh, 
terpadu oleh masyarakat dan keluarga. Tujuannya untuk mewujudkan keluarga kecil bahagia, sejahtera bertakwa kepada Tuhan yang Maha Esa, produktif, mandiri, dan memiliki kemampuan untuk membangun diri sendiri dan lingkungannya.

\subsubsection{Faktor yang Mempengaruhi} Kesejahteraan Keluarga

Beberapa faktor yang mempengaruhi kesejahteraan keluarga, diantaranya:

1. Jumlah Anggota Keluarga

Pada zaman sekarang, tuntutan keluarga semakin meningkat tidak hanya cukup dengan kebutuhan primer (sandang, pangan, papan, pendidikan, sarana pendidikan) tetapi kebutuhan lainnya seperti hiburan, rekreasi, sarana ibadah, sarana untuk transportasi dan lingkungan yang serasi. Kebutuhan di atas akan lebih memungkinkan terpenuhi jika jumlah anggota dalam keluarga itu kecil.

2. Tempat Tinggal

Suasana tempat tinggal sangat mempengaruhi kesejahteraan keluarga. Keadaan tempat tinggal yang diatur sesuai dengan selera keindahan penghuninya, akan lebih menimbulkan suasana yang tenang dan menggembirakan serta menyejukkan hati. Sebaliknya tempat tinggal yang tidak teratur, tidak jarang menimbulkan kebosanan untuk ditempati. Kadang-kadang sering terjadi ketegangan antara anggota keluarga yang disebabkan kekacauan pikiran karena tidak memperoleh rasa nyaman dan tenteram akibat tidak teraturnya sasaran dan keadaan tempat tinggal.

3. Keadaan Sosial Ekonomi

Untuk mendapatkan kesejahteraan keluarga alasan yang paling kuat adalah keadaan sosial dalam keluarga. Keadaan sosial dalam keluarga dapat dikatakan baik atau harmonis, bilamana ada hubungan yang baik dan benar-benar didasari ketulusan hati dan rasa kasih sayang antara anggota keluarga. Manifestasi daripada hubungan yang benar-benar didasari ketulusan hati dan rasa penuh kasih sayang, nampak dengan adanya saling hormat menghormati, toleransi, bantu membantu dan saling mempercayai. Ekonomi dalam keluarga meliputi keuangan dan sumber-sumber yang dapat meningkatkan taraf hidup anggota keluarga (BKKBN, 1994:1821).

Namun dalam kisah Men Brayut dengan kedelapan belas anaknya, keluarga yang sejahtera dapat terjadi meskipun jumlah anggota keluarga tersebut dapat dikatakan melebihi batas yang ditentukan dalam ukuran kesejahteraan keluarga. Dengan kesabaran dan keteguhan serta kepasrahan terhadap keadaan, maka keluarga tersebut dapat menjadi keluarga yang sejahtera, dibuktikan dengan keadaan keluarga tersebut yang selalu rukun dan bahagia, serta anak-anaknya yang telah tumbuh dewasa semuanya memiliki penampilan fisik yang baik dan juga mempunyai pengetahuan akan sastra yang juga mumpuni. Selain itu keluarga Pan Brayut dikatakan sejahtera karena memenuhi syarat dari ciri-ciri keluarga sejahtera, yaitu saling terbuka antar anggota keluarga, adanya saling kerjasama antar keluarga, terjadi komunikasi yang baik antar anggota keluarga.

Keluarga sejahtera merupakan output dari dinamika proses pengelolaan sumber daya serta masalah-masalah dalam keluarga. Kondisi tersebut dikenal dengan ketahanan keluarga, seperti pengertian yang diberikan UU No. 10 Tahun 1992 pasal 1 ayat 15 yaitu :"Kondisi dinamik suatu keluarga yang memiliki keuletan dan ketangguhan serta mengandung kemampuan fisik material dan psikis mental spiritual guna hidup mandiri dan mengembangkan diri dan keluarganya untuk hidup harmonis dalam meningkatkan kesejahteraan lahir batin" (BKKBN:1992)

\subsection{Pengasuhan Anak}

Keluarga merupakan kelompok masyarakat terkecil yang terbentuk oleh ikatan dua orang dewasa yang berlainan jenis kelamin, pria dan wanita serta anak-anak yang 
dilahirkan. Dalam kelompok arus kehidupan dikendalikan oleh orangtua. Alam mempercayakan pertumbuhan serta perkembangan anak pada orangtua. Fungsi keluarga yang utama adalah mendidik anakanaknya. Orangtua dikatakan pendidik utama dan pertama bagi anak-anak mereka. Dengan demikian bentuk pertama dari pendidikan terdapat dalam keluarga. Keluarga memberikan dasar pembentukan tingkah laku, watak, moral dan pendidikan anak.

Mengasuh anak berarti mendidik, membimbing, dan memeliharanya mulai dari mengurus makanan, minuman, pakaian, kebersihan atau pada segala perkara yang seharusnya diperlukan, sampai batas bilamana si anak telah mampu melaksanakan keperluannya yang vital tersebut.

\subsubsection{Fungsi Keluarga}

Keluarga sebagai sebuah sistem sosial mempunyai tugas atau fungsi agar sistem tersebut berjalan. Tugas tersebut berkaitan dengan pencapaian tujuan, integrasi dan solidaritas, serta pola kesinambungan atau pemeliharaan keluarga (Megawangi, 1999:72). Majelis umum PBB menguraikan fungsi umum keluarga adalah sebagai wahana untuk mendidik, mengasuh dan sosialisasi anak, mengembangkan kemampuan seluruh anggotanya agar menjalankan fungsinya di masyarakat dengan baik, serta memberikan kepuasan dan lingkungan sosial yang sehat guna tercapainya keluarga sejahtera (Megawangi, 1994:77).

\subsubsection{Peran Keluarga dalam Pembangunan SDM}

Dilandasi pengertian kualitas sebagai gabungan karakteristik yang menentukan derajat kehandalan, Hidayat Syarief (1997:42) mendefinisikan kualitas SDM (Sumber Daya Manusia) sebagai gabungan dari karakteristik segenap sumber daya yang ada dalamdiri manusia, mencakup karakteristik fisik, akal, kalbu, dan nafsu yang menentukan derajat kehandalan manusia baik sebagai makhluk individu maupun makhluk sosial. Investasi untuk pengembangan anak usia dini memiliki arti penting dengan berbagai alasan yaitu:
1) Membangun SDM yang berkemampuan intelegensia tinggi, berkepribadian dan berperilaku sosial yang baik serta mempunyai ketahanan mental dan psikososial yang kokoh, 2) menghasilkan nilai ekonomi yang lebih tinggi dan menurunkan biaya sosial di masa datang dengan meningkatkan efektivitas pendidikan, 3) mencapai pemerataan sosial ekonomi masyarakat, termasuk mengatasi kesenjangan gender, 4) meningkatkan efisiensi investasi pada sektor yang lain karena intervensi program gizi dan kesehatan pada anak-anak akan mneingkatkan kemungkinan kelangsungan hidup anak, sedangkan intervensi dalam program pendidikan akan meningkatkan kinerja anak dan mengurangi kemungkinan tinggal kelas, 5) membantu kaum ibu dan anak-anak dengan semakin meningkatnya jumlah ibu bekerja dan kepala rumah tangga wanita, pemeliharaan anak yang aman menjadi semakin penting"

\subsubsection{Keluarga Sebagai Institusi Utama dalam Pengembangan SDM \\ Keluarga sebagai institusi utama} dalam pengembangan SDM dilandasi oleh kenyataan bahwa aktivitas utama kehidupan berlangsung di keluarga. Peran keluarga yang berhubungan dengan fungsi ekonomi menjadi penting sebagai cerminan daya beli keluarga untuk memenuhi kebutuhan fisik seperti makan, pakaian, tempat berteduh, memperoleh pendidikan, dan memperoleh pelayanan kesehatan. Peran keluarga yang berhubungan dengan fungsi cinta kasih juga sangat berperan dalam memberikan lingkungan psikologi yang sehat bagi semua anggota keluarga untuk tumbuh dan berkembang mencapai potensi optimum. Dalam perspektif itu salah satu gerakan pembangunan keluarga sejahtera dilakukan melalui optimalisasi fungsi keluarga (BKKBN:1996). 
Keluarga sebagai institusi utama dalam pengembangan SDM juga berkaitan dengan fungsi sosialisasi. Sosialisasi merupakan proses dimana individu mendapatkan pengetahuan, keterampilan, dan karakter yang memungkinkannya berpartisipasi sebagai anggota kelompok atau masyarakat yang efektif (Berns, dalam Brim, 1997:97), oleh karenanya berlangsung seumur hidup. Sosialisasi memungkinkan anak mengembangkan potensi dan membentuk hubungan kepuasan melalui pengembangan konsep diri, penanaman konsep disiplin, penanaman ambisi, pengajaran peran sosial, dan pengajaran keterampilan.

Berbagai tujuan dan manfaat sosialisasi seperti telah dikemukakan, menunjukkan kompetensi kecerdasan emosional (emotionalintelligence), yang semakin disadari merupakan faktor yang penting dalam keberhasilan seorang individu.

Pada teks geguritan Brayut, konsep pengasuhan anak terwujud dengan baik. Ada pembagian tugas antara suami dan istri. Pan Brayut mau membantu istrinya untuk mengurus pekerjaan rumah tangga sedangkan istrinya fokus mengurus anak-anaknya yang berjumlah delapan belas. Dalam kehidupan dengan keadaan ekonomi yang awalnya terbatas, Pan Brayut dan Men Brayut sukses mendidik dan membimbing anak-anaknya menjadi pribadi yang mumpuni sehingga banyak orang yang mengidam-idamkan anaknya untuk meminang.

\subsubsection{Pemberian ASI Eksklusif Pada Anak}

Selain ayah, ibu memiliki peranan penting dalam sebuah keluarga. Seorang ibu mempunyai tugas untuk mengurus keluarga, salah satunya membesarkan anak-anak. Pada zaman modern seperti sekarang ini, terutama di kota-kota besar, banyak kaum ibu yang bukan hanya menjalankan kewajibannya sebagai ibu rumah tangga saja, namun ada juga yang bekerja membantu suami untuk mencari nafkah dalam upaya memenuhi kebutuhan hidup yang semakin meningkat. Salah satu contohnya, di Bali ibu-ibu bukan hanya mengurus rumah tangga dan bekerja, namun jug menjalankan aktifitas sosial seperti ngayah atau ngoopin. Walaupun demikian, seorang ibu tidak boleh melupakan tugas utamanya mengurus keluarga dengan penuh kasih sayang dan rasa tulus. Apalagi bagi yang memiliki bayi dan memutuskan untuk memberi ASI (Air Susu Ibu) eksklusif sampai usia 6 bulan untuk semester pertama dan sampai usia 2 tahun untuk semester dua.

Men Brayut dalam teks geguritan Brayut menceritakan tentang pengabdian seorang wanita pada keluarganya. Men Brayut adalah tokoh seorang ibu dalam cerita klasik masyarakat Bali yang melahirkan anak hingga delapan belas orang dan anak-anaknya sangat dekat secara emosional dengan ibunya. Semua anaknya menempel dan ingin bermanja-manja dengan ibunya. Maka dari itu tokoh Men Brayut sudah lama menjadi ikon kesuburan bagi masyarakat Bali. Men Brayut sebagai ibu yang sabar, tabah dan gigih dalam mengurus anak-anaknya sehingga semua anak-anaknya menjadi anak yang cantik, tampan dan cerdas serta memiliki pengetahuan sastra yang baik. Sebagai seorang ibu rumah tangga dan dengan keadaan ekonomi yang tidak begitu baik, ia sukses memelihara dan merawat anaknya, dengan memberikan asi eksklusif sebagai makanan utama anaknya yang bayi.

Sehingga tidak mengherankan jika sekarang tokoh Men Brayut dijadikan sebagai ilustrasi ikon kampanye ASI eksklusif bagi ibu bekerja.

Berikut adalah beberapa kutipan yang menyatakan bahwa Men Brayut memberikan asi pada anak-anaknya.

tuah katuduh kento naan, arang yen tong tani beling, sepan mambelas malendong, basange suba maisi, tatang kober angangantih, ya ke manglikas manunun, jani tulus mangebong, pianake bek pagalanting, medem bangun, awake ludin limuhan.

Terjemahan:

memang kehendak Tuhan, jarang hamilnya tak jadi, belum nyapih sudah hamil, 
perutnya sudah berisi,

sehingga tak bisa memintal benang,

apalagi menenun,

sekarang tinggal di rumah saja,

anak-anaknya banyak,

bangun tidur saja,

sehingga badannya kepayahan.

Pada kutipan di atas terdapat kata "sepan mabelas mablendong" yang berarti belum nyapih sudah hamil lagi. Nyapih adalah kegiatan meghentikan memberi asi pada anak secara terencana dikarenakan usia anak yang sudah cukup umur untuk tidak minum asi lagi. Kutipan di bawah ini juga memperkuat pernyataan tersebut.

lene bangun manalabang,

bahu kedat nagih nasi,

ada mangrebutin nyonyo,

magujeg pada mangeling,

lene manguring-uring,

pacara mantigang bungbung,

ada ngocok kakocor,

ne nyoman mangagas dingding,

pabiyayuh elingne matrayuhan.

Terjemahan:

ada juga yang baru terbangun,

baru buka mata minta nasi,

ada yang merebut susu ibunya,

pada menangis,

ada yang membujuk,

membanting perabotan,

ada yang merusak tempat air,

anak yang ketiga mengorek dinding,

sangat gaduh,

tangisnya amat riuh.

Pada kutipan di atas terdapat kata " $a d a$ mangrebutin nyonyo" yang berarti pada memperebutkan susu ibunya. Kutipan tersebut menggambarkan anak-anak Men Brayut merebut susu ibunya karena semua anaknya minum asi eksklusif dari Men Brayut. Kedua kutipan di atas jelas mengatakan bahwa Men Brayut memberikan asi eksklusif pada anak-anaknya semasih mereka bayi.

\subsection{Sistem Kekerabatan}

\subsubsection{Definisi Sistem Kekerabatan}

Sistem kekerabatan merupakan bagian yang sangat penting dalam struktur sosial. Meyer Fortes (1999:25) mengemukakan bahwa sistem kekerabatan suatu masyarakat dapat digunakan untuk menggambarkan struktur sosial dari masyarakat yang bersangkutan. Kekerabatan adalah unit-unit sosial yang terdiri dari beberapa keluarga yang memiliki hubungan darah atau hubungan perkawinan. Anggota kekerabatan terdiri atas ayah, ibu, anak, menantu, cucu, kakak, adik, paman, bibi, nenek, kakek dan seterusnya. Stuktur-struktur kekerabatan mencakup kekeluargaan dan bentuk kelompok yang merupakan perluasan keluarga seperti suku atau klen (dadia).

Ikatan diantara orang yang bukan kerabat melahirkan banyak macam bentuk pengelompokan mulai dari "persaudaraan sedarah" sampai persahabatan semacam "perkumpulan". Umur dan ikatan yang terbentuk karena keinginan sendiri termasuk ke dalam kategori bukan kerabat. Kekerabatan atau kekeluargaan merupakan hubungan antara manusia yang memiliki asal usul silsilah yang sama, baik melalui keturunan biologis sosial maupun budaya. Dalam bahasa Indonesia ada istilah sanak saudara, kaum kerabat, ipar besan, yang dapat diartikan dengan kata family. Kata family berasal dari bahasa Belanda dan Inggris yang sudah umum dipakai dalam bahasa Indonesia sehingga dapat dikatakan ia telah di Indonesiasi.

Dalam antropolgi sistem kekerabatan termasuk keturunan dan pernikahan (melalui hubungan darah atau dengan melalui hubungan status perkawinan). Pengertian bahwa seseorang dinyatakan sebagai kerabat bila ia memiliki pertalian atau ikatan darah dengan seseorang lainnya, contoh konkrit dari hubungan darah adalah kakak-adik sekandung.

Hubungan melalui perkawinan adalah bila seseorang menikah dengan saudaranya, maka ia menjadi kerabat atau seseorang yang dikawini oleh saudaranya merupakan contoh konkrit dari hubungan perkawinan adalah adik ipar atau kakak ipar, bibi, dari adik ibu. 
Manusia melalui pernikahan umum disebut sebagai "hubungan dekat" ketimbang keturunan (juga disebut konsunguitas), meskipun kedua hal itu bisa tumpang tindih dalam pernikahan diantara orang satu moyang. Hubungan kekerabatan adalah salah satu prinsip mendasar untuk mengelompokkan tipe orang ke dalam kelompok sosial, peran kategori dan silsilah, hubungan kekeluargaan dapat dihadirkan secara nyata (ibu saudara kakek) atau secara abstrak menurut tingkatan kekerabatan sebuah hubungan dapat memiliki syarat relatif (misalnya ayah adalah seorang yang memiliki anak). Terdapat dua sistem kekerabatan, yaitu sistem kekerabatan patrilineal dan sistem kekerabatan matrilineal.

\subsubsection{Sistem Kekerabatan Patrilineal \\ Patrilineal adalah suatu adat} masyarakat yang mengatur alur keturunan berasal dari pihak ayah. Kata ini seringkali disamakan dengan patriarkat atau patriarki, meskipun pada dasarnya artinya berbeda. Patrilineal berasal dari dua kata bahasa latin, yaitu pateryang berarti ayah, dan linea berarti garis. Jadi, patrilineal berarti mengikuti garis keturunan yang ditarik dari pihak ayah. Sementara itu patriarkat berasal dari dua kata bahasa Yunani, yaitu pater yang berarti "ayah", dan archein yang berarti memerintah. Jadi patriarki berarti kekuasaan berada di tangan ayah atau pihak laki-laki.

\subsubsection{Sistem Kekerabatan Matrilineal}

Sistem kekerabatan matrilineal yaitu

sistem kekerabatan berdasarkan garis

keturunan ibu. Adapun ciri-ciri dari sistem kekerabatan matrilineal sebagai berikut:

1. Keturunan dihitung menurut garis ibu

2. Suku terbentuk menurut garis ibu

3. Tiap orang diharuskan kawin dengan orang luar sukunya atau eksogami

4. Pembalasan dendam merupakan suatu kewajiban bagi seluruh suku

5. Perkawinan bersifat matrilokal, yaitu suami mengunjungi dan tinggal di rumah istrinya

6. Hak-hak dan pusaka diwariskan oleh ibu pada keponakan atau dari saudara laki-laki ibu pada anak dari saudara perempuan.

Dalam teks geguritan Brayut, sistem kekerabatan yang berasal dari satu darah yang ditampilkan adalah antara ayah, ibu, adik, kakak dan menantu. Pan Brayut sebagai ayah, Men Brayut sebagai ibu serta kedelapan belas anak-anaknya yang terdiri dari adik dan kakak sekandung yang tidak disebutkan dengan jelas nama dari masing-masing namanya. Sistem kekerabatan yang mencolok dari cerita Brayut ini adalah hubungan kekerabatan antara adik dan kakak yang berjumlah delapan belas orang. Hal yang menjadi titik perhatian adalah pada pemberian nama masing-masing anak tersebut.

Hal ini pula yang menjadi keunikan dari budaya Bali. Dimana orang Bali begitu kuat dan taat untuk tetap ingat darimana dirinya berasal sehingga melahirkan berbagai golongan masyarakat yang dikenal dengan wangsa atau soroh. Begitu pula dengan sistem penamaan keluarga Bali berdasarkan wangsa atau soroh tersebut (Sastra Kanda Pat Sari). Pada wangsa Brahmana pemberian nama Ida Bagus untuk anak laki-laki dan Ida Ayu untuk anak perempuan. Pada wangsa Ksatriya diberikan nama Anak Agung baik untuk pria maupun wanita. Pada keluarga Waisya diberikan nama Gusti Ngurah untuk laki-laki dan Gusti Ayu untuk perempuan. Sedangkan dari wangsa Sudra diberikan nama Wayan/Putu untuk anak pertama, Kadek atau Made untuk anak kedua, Komang atau Nyoman untuk anak ketiga dan Ketut untuk anak keempat. Nama depan tersebut diberikan pada anak laki-laki atau perempuan.

Dalam kasus memiliki anak banyak (melebihi 4 orang sampai batas nama Ketut), maka pemberian nama depan akan berulang kembali dan menjadi Wayan/Putu balik, Kadek/Made Balik, Komang/Nyoman Balik dan Ketut Balik. Begitupula yang terjadi pada keluarga Brayut. Pemberian nama Wayan / Putu, Kadek / Made, Komang / Nyoman dan Ketut diberikan berulang sampai hampir lima kali.

Pada teks geguritan Brayut hal pemberian nama tersebut dipaparkan dalam 
beberapa bait sehingga menunjukkan sistem kekerabatan yang tampak jelas.

Kisah Brayut dimana tempat terjadinya adalah di Bali dan diceritakan bahwa keluarga ini menganut agama Hindu/Budha, maka sistem kekerabatan yang dianut adalah sistem kekerabatan patrilineal. Anak-anak Pan Brayut dan Men Brayut yang laki-laki dan sudah memiliki istri masih tinggal di rumah, karena mereka merupakan ahli waris keluarga dan yang akan memberikan generasi penerus bagi keluarga tersebut. Sedangkan anak-anaknya yang perempuan dan sudah menikah akan mapamit dari rumah tersebut dan akan mengikuti dimana suaminya tinggal.

\section{SIMPULAN}

Berdasarkan penjelasan di atas dapat disimpulkan bahwa hubungan geguritan Brayut dengan sosial budaya masyarakat Bali dianalisis dari berbagai aspek, yaitu perkawinan menurut Hindu, kesejahteraan keluarga, masalah pengasuhan anak dan sistem kekerabatan. Semua aspek tersebut membentuk satu kesatuan yang tidak dapat dipisahkan satu sama lain. Penjelasan ini diperkuat dengan kutipan-kutipan yang mendukung aspek-aspek tersebut dan memang terdapat pada teks.

\section{DAFTAR PUSTAKA}

BKKBN. 1994. Rencana Strategis Program KB Nasional. Jakarta: BKKBN Pusat

Djoko Damono, Sapardi. 2005. Psikologi Sastra. Jakarta: Pusat Pembinaan dan Pengembangan Bahasa, Departemen Pendidikan dan Kebudayaan

Megawangi, R. 1999. Membiarkan Berbeda. Sudut Pandang Bari Tentang Relasi Gender. Bandung: Mizan Pustaka

Rambe, Armaini. 2004. Alokasi Pengeluaran Rumah Tangga dan Tingkat Kesejahteraan.

Soembodo, Benny. 2004. Persepsi Masyarakat Petani Miskin Mengenai Kesejahteraan keluarga.

Teeuw, A. 1984. Sastra dan Ilmu Sastra Pengantar Teori Sastra. Jakarta: Pustaka Jaya. 